\title{
Are You an Excellent International Entrepreneur?-Building a Competency Model of International Entrepreneurs Based on the Grounded Theory
}

\author{
Ying Pan \\ School of Business Administration, South China University of Technology, Guangzhou, China \\ Email: bmpan@mail.scut.edu.cn
}

How to cite this paper: Pan, Y. (2017) Are You an Excellent International Entrepreneur?-Building a Competency Model of International Entrepreneurs Based on the Grounded Theory. Journal of Service Science and Management, 10, 394-411. https://doi.org/10.4236/jssm.2017.104032

Received: July 20, 2017

Accepted: August 19, 2017

Published: August 22, 2017

Copyright $\odot 2017$ by author and Scientific Research Publishing Inc. This work is licensed under the Creative Commons Attribution International License (CC BY 4.0).

http://creativecommons.org/licenses/by/4.0/

(c) (i) Open Access

\begin{abstract}
With the deepening of global economic integration process, the survival and development of enterprises is facing a severe test. An excellent international entrepreneur is the personification of the enterprise, undertaking the mission of making corporate development strategy, who can lead the enterprise to expand, innovate and achieve continuously in the multinational operation. In order to study the abilities and qualities of excellent international entrepreneurs, we conducted depth interviews with five professors from business school of universities, three industry experts, seven international entrepreneurs and eleven subordinates from several Chinese large multinational enterprises, receiving a large amount of the first and second-hand data. Then, we use grounded theory to process, match, classify and extract data by means of open coding, axial coding and selective coding, building a competency model of international entrepreneurs, including three main categories and seventeen sub-categories. The first main category is Knowledge, an objective evaluation, including three sub-categories, such as managerial professional knowledge, language proficiency and the knowledge of international business. The second main category is Ability, including eight sub-categories, such as the managerial competencies of international enterprises, cognitive ability of international market, the ability of international trade, the ability to adapt to the dynamic environment, the ability to integrate domestic and foreign resources, the ability to overcome crisis and risks, relationship ability with society and government and learning ability. The third main category is Personality, including six sub-categories, such as autonomy, innovation, change, advance cognition and action, competition enthusiasm and the spirit of adventure.
\end{abstract}

\section{Keywords}

International Entrepreneur, Competency Model, Coding, Grounded Theory 


\section{Introduction}

As is known to all, with the rapid development of economic globalization and market economy, more and more enterprises grow into worldwide multinational enterprises. For international enterprises which aspire to participate in competition in international market, it is undoubtedly an important guarantee for them to obtain sustainable development to better promote the construction of entrepreneur qualities and abilities. International entrepreneurs, to a great extent, are the most important human resources of enterprises and the important leaders towards the direction of development [1]. Entrepreneur qualities and abilities, on the one hand, reflect an enterprise's prospect. On the other hand, they reveal whether an enterprise has the potential to obtain core competitiveness in fierce market competition. Therefore, to seek innovative development, it is a bounden duty for many enterprises, especially those that aspire to move towards the international market, to train entrepreneurs with an international view and abilities in the true sense.

Besides, the improvement of entrepreneur qualities, abilities, skills and levels is not the work of a single day and cannot be achieved very easily. On the one hand, the training of entrepreneur abilities and qualities relies on individual awareness and growth of entrepreneurs [2]. On the other hand, it must keep pace with the development and internationalization of enterprises [3]. Only when "sharing a common fate" with the enterprise, will an entrepreneur's growth and progress become the support of corporate development and corporate development benefit from the progress of the entrepreneur [4]. Therefore, they are complementary to each other and form an important "community of common destiny". So based on this background and pursuit, from the general context of global economic integration and rapid development of market economy, we try to explore ideas and methods to build a competency model of international entrepreneurs. It is undoubtedly of great practical significance for unscrambling and interpreting the above topic.

\section{Theoretical Background}

\subsection{International Enterprises}

International enterprises, or multinational enterprises, are economic entities that have or control production or service facilities outside the country where they are located, and operate activities such as production, sale and service across national boundaries.

Domestic enterprises are in a country's economic system, while international business activities are in the international economic system. There are many differences between them. First, the business market environment of international enterprises is more complex. The goods, technology, services and capital of international enterprises are to meet the needs of consumers in the world market, and their operations are closely related to the international political, economic, cultural and other environments. Compared with the domestic enterprises, the 
international market environment they face has a wider range and bigger difference, and it is more difficult to identify, evaluate, predict, adapt, and control. Second, international enterprises are much riskier. In addition to the operational risks of domestic enterprises, international enterprises also face with some international risks, such as the host country political instability [5], the collection of international business property, the limit of host country on the transfer of funds, exchange rate changes, tax discrimination [6], double taxation, etc. Third, the multi-national conflict. The business activities of international enterprises are often caused by conflicts of capital, production, employment, foreign exchange and national economic treatment due to the differences between shareholders, employees, customers and suppliers, and the differences between the economic policies of the host country and the decision-making of international business interests [7]. Fourth, international enterprises need newer management thoughts and methods. Because of the environment, risk and conflict of international enterprises, the management thoughts and methods of domestic enterprises is not enough [8], in addition to expand the information system, organization system, and management technology of enterprise management, but also develop new business strategies and management methods.

\subsection{International Entrepreneurs}

1) The Concept of International Entrepreneurs

In the 1990s, the theory of international entrepreneurs emerged from the research field of multinational corporations. The research object was the multinational entrepreneur who worked in the international environment and carried out the international enterprise management and decision-making [9]. The researches mainly focused on the discovery, utilization and excavation of international business opportunities for international entrepreneurs.

The term "international entrepreneur" first appeared in Morrow's paper, which discussed how to open up the latest technology and cultural awareness of the newly developed foreign markets for the new company and to understand innovation as a core element in the concept of international entrepreneurs [10]. Oviatt \& McDongall (1994) presented an analytical framework for international start-ups and discussed the importance of researches on international entrepreneurship in combination with the researches of international business, entrepreneurship and strategic management [11]. The research of international entrepreneur begins with the study of international start-ups, but it is different from or even beyond the research of international start-ups. International business scholars Wright \& Ricks (1994) argued that international entrepreneurs are an emerging research area. The study of international entrepreneurs mainly includes two aspects: first, under the multi-national and multicultural background, the comparison of entrepreneurial behaviors; second, by the expansion to the border, the comparison of corporate behavior [12]. Due to the different understanding of the core connotation of international entrepreneurs, scholars have 
defined the international entrepreneurs from different perspectives. In keeping with the generally accepted concept of "international business", McDongall \& Oviatt (1997) ruled out the study of nonprofit and government organizations, defining international entrepreneurs as "a combination of innovative, proactive and risk-seeking behavior that crosses national borders and is intended to create value in organizations" [13]. Considering that the new organization is not necessarily in a stable situation when creating a new organization, Shane \& Venkataraman (2000) explained international entrepreneurs as "examination of how, by whom, and with what effects opportunities to create future goods and services are discovered, evaluated, and exploited" [14]. In 2005, Oviatt \& McDongall concerned more about opportunity on the basis of their original research, and the definition of international entrepreneurs was perfected, "International entrepreneurship is the discovery, enactment, evaluation, and exploitation of opportunities-across national borders-to create future goods and services" [15].

On the basis of emphasizing the international background and drawing lessons from the predecessors' theory, this paper holds that the international entrepreneurs are the multidimensional enterprises who operate the multinational enterprises as the occupation, coordinate the enterprise production and the transaction activity, have the global vision and the international management ability, identify and take advantage of business opportunities, continue to make judicious decisions or innovations, and take the risk of them.

2) The Characteristics of International Entrepreneurs

Due to the international business activities and domestic business activities or traditional foreign trade have a significant difference, the international entrepreneurs have different characteristics with the domestic entrepreneurs in addition to some general characteristics of entrepreneurs [16]. The particularity of international business activities requires international entrepreneurs to have higher quality than domestic entrepreneurs and show different characteristics.

International adaptability enables the excellent international entrepreneur to adjust their leadership style and operation mode according to different national conditions and cultural demand. These excellent international entrepreneurs usually manage and operate enterprises in different countries and cultures. They are good at managing and controlling their inherent cultural tendency, and meanwhile they adjust the management style according to different countries and cultures [17]. As research shows, in different cultures and countries, they often show the flexibility in the following three aspects: establishment of business relationship, foundation of action taken, way of power implementation. In terms of establishing business relationship, they are not only good at operating in the culture requiring the establishment of personal relationship, but also good at developing business relationship in the culture emphasizing contractual relationship. In the culture emphasizing personal relationship, these entrepreneurs attach importance to mutual trust and mutual respect. Sometimes, they may pay more attention to long-term personal relationship rather than short-term busi- 
ness interest [18]. Another feature is that they know the significance of saving face. Instead of despising others' wisdom and experience, they respect the authority, status, age and others of business partnerships who have different cultures [19]. They are wholehearted and rather skillful in establishing personal relationship, and they know how to establish and strengthen personal relationship and business relationship by formal and informal communication. In the culture emphasizing contractual relationship, an excellent international entrepreneur can well separate personal emotion and business requirement. They are good at maintaining objectivity in business activities and building up trust and respecting by contract completion. At the same time, they pay more attention to business result rather than interpersonal relationship. In terms of action, the research on the international entrepreneur finds out the emphasis on plan and the emphasis on implementation are contradictory [20]. The emphasis on plan focuses on the consideration and logicality of the plan [21]. They often make a very detailed plan and do research on several possibilities and scenarios, and they will determine the implementation steps in advance and explain the necessity of action to their subordinates. The emphasis on implementation is inclined to take actions by an experimental, freestyle and practical method. They focus on selecting appropriate staff to carry out the plan, and they are good at evaluating the staff and establishing an effective team to let them cooperate and complement each other. At the same time, they have fullest confidence in the selected subordinate's implementation capability. They do things with a sense of urgency and decisiveness, and they hate bureaucracy. Besides, they emphasize that the detailed plan is appropriate and impossible in the unstable and fast-changing environment. In terms of power implementation, the research on the international entrepreneur also finds out the centralized leadership and participative leadership are contradictory. The entrepreneur with centralized leadership will definitely show others they are leaders and decision-maker. At same time, they will describe and spread their prospect to the subordinates and often take responsibility of action independently [22]. They believe their prospect is correct and can effectively overcome the difficulties and barriers on the road ahead. The international entrepreneur with participative leadership competency is good at creating organization atmosphere and frame to let the all team make contribution [23]. They respect others' ability and contribution, and also welcome the subordinates' advice and suggestion. They like to share information with the subordinates and encourage them to make more contribution.

\section{Research Design}

\subsection{Participants}

In order to study the abilities and qualities of excellent international entrepreneurs, we invited five professors from business school of universities, three industry experts, seven international entrepreneurs and eleven subordinates from Chinese large multinational enterprises to conduct depth interviews and we re- 
ceived a large amount of the first and second-hand data.

\subsection{Method}

We use grounded theory to analyze the interview data. Qualitative research is through the interaction between the researcher and the object of study to carry out in-depth and meticulous research, and then to get a more comprehensive understanding of the nature of things. The grounded theory was a method of constructing the theory founded by American scholars Glaser \& Strauss (1967). This is a way of linking theory with experience, abstraction and concrete [24]. The core of the theoretical approach is the process of data collection and analysis, which includes both theoretical illation and theoretical induction. The collection and analysis of data is the process of simultaneous occurrence and continuous circulation. The data collection method is the same as other qualitative research, and the data analysis is strict. Strauss argues that the analysis of the data is called coding, that is, the text of the collected or translated text is decomposed, analyzed, making the concept of the initial conceptualization, and then making the initial conceptualization into the second conceptualization and abstraction, and then reuse the concept of the third abstraction, promotion and integration as the categories and the core areas of the operation process in the appropriate way. The process should be faithful to the information, dig out the scope of the data, and identify the nature of the categories and the nature of the dimensions. The complex relationship between the categories is the study of the relationship between the theories. The purpose of grounded theory study is to describe the nature and significance of the phenomenon from the theoretical level, so as to establish a suitable theory.

\section{Results}

The analysis process of the grounded theory can be divided into three main steps, followed by open coding, axial coding and selective coding.

\subsection{Open Coding}

Open coding refers to the conceptualization and categorization of enterprise data records, that is, according to certain principles making a large number of data records to step by step down, with the concept and category to correctly reflect the information, and breaking the information recorded and abstract concept completely, sorting, reorganizing and summarizing the process. The purpose of open coding is to identify phenomena, define concepts, and find categories, that is, deal with convergence problems. Through open coding, we got seventeen sub-categories from the interview record in Table 1.

Ability of international trade. International entrepreneurs are global strategists. The production, sales and service of international enterprises in distribute around the world. They face the intricate and varied international business environment, which requires international entrepreneurs in the scientific analysis of the international business environment and its own operating conditions 
Table 1. Categorizing results from open coding.

\begin{tabular}{cc}
\hline \multicolumn{2}{c}{ Sub-categories } \\
\hline $\begin{array}{c}\text { Ability of international trade } \\
\text { Managerial professional knowledge }\end{array}$ & Learning ability \\
Ability to adapt to the dynamic environment \\
Change & Ability to overcome crisis and risks \\
Ability to integrate domestic and \\
foreign resources \\
Language proficiency \\
Competition enthusiasm \\
Autonomy \\
Cognitive ability of international market \\
Rerial ability of international enterprises \\
Relationship ability with society and government \\
\hline
\end{tabular}

on the basis of long-term survival and development to make the overall longterm strategy. They take the global competition from the field of vision and way of thinking to consider the fierce competition from any country and region and the change and constraints of various environmental factors [25]. They need to make a variety of limited resources to make the most reasonable configuration and use of a variety of markets to make a reasonable choice, combination and effective entry.

Managerial professional knowledge. Managerial professional knowledge is the most basic quality that an excellent entrepreneur should have. "Knowledge is power." The leaders of modern enterprises cannot manage with experience alone. They must have a wide range of knowledge to make enterprises invincible even though facing the highly competitive market. Entrepreneurs should grasp the basic principles of enterprise management methods and related professional management knowledge, and understand the development of modern management theory at home and abroad. Sometimes, business managers need to enter into the middle and even the grassroots to check the guidance work, so the management of knowledge cannot just be general understood, at least to master, it is best proficient, so as to better assume the responsibility of leadership. What's more, not only master the knowledge on the books, but also on the basis of experience to obtain the sublimation and integration.

Ability to adapt to the dynamic environment. The identification of the external market environment by the international entrepreneur is the necessary condition for the entrepreneur to formulate the strategy of the development of the enterprise. With the time passing by, the environment of the enterprise will change constantly. Therefore, to maintain the sustainable development of the enterprise, the international entrepreneur must dynamically adjust their own learning ability, so as to lead and encourage the team to learn to adapt to the dynamic environment.

Change. As an important way of social evolution, change is the driving force of human progress and plays an important role in enhancing the competitive- 
ness of enterprises. Under the complex external environment and the changeable internal environment, it is likely to face their own competitive advantage gradually weakened for international enterprises. In this case, the implementation of organizational change has become a critical opportunity for organizational survival and development [26]. The success or failure of organizational change should largely be attributed to entrepreneurs. International entrepreneurs should be able to lead the organization members in accordance with the goal of change, to be good at discovering or even to create willing followers, to understand their own business, personnel and operating environment. As a strategist, the international entrepreneur is concerned about the future, to understand the latest trends, emphasizing the purpose and direction, depicting the blueprint of the company's development vision. As a propaganda agitator, he is concerned about people's dedication, emphasizing the value of the company with new goals. And as an analyst, he is concerned about the company's operational efficiency, assessment plans and projects to coordinate conflicting views and needs. As a foreman, he is concerned about performance, emphasizing the results, solving the problem, and influencing the lower decision making.

Ability to integrate domestic and foreign resources. Resource integration is a systematic way of thinking. It is through the organization and coordination, to integrate the internal functions in relations with each other but separated from each other and the external partners with common mission and independent economic interests into a customer service system to make effect better [27]. The integration of international enterprises is the decision of optimal allocation. International entrepreneurs need to reconfigure the relevant domestic and foreign resources according to the development strategy and market demand of the enterprise to highlight the core competitiveness of the enterprise and seek the best combination of resource allocation and customer demand, thus enhancing the competitive advantage of the enterprise.

Language proficiency. It is a necessary requirement for enterprises to skilled use an international common language in order to go abroad and cooperate with other enterprises in the world. Not only should the first-line traders of enterprises, international entrepreneurs also have a high level of foreign language. It is importance of a direct understanding of foreign customs and local policy trends, making business negotiations, maintaining friendly channels of communication, and creating cross-cultural staff closer relationship.

Competition enthusiasm. As the core of the enterprise, international entrepreneurs have the important responsibility to lead the enterprises to success. Entrepreneurs themselves should maintain a positive attitude, not be afraid to lead the company to participate in international competition, and make this point as their mission to overcome all the problems to achieve the goal. This spirit of international entrepreneurs can be formed within the company to make a positive atmosphere of energy, a great extent infected with their employees in their respective work on the initiative to make the whole enterprise on the path of healthy development. 
Autonomy. A good international entrepreneur should have a certain degree of autonomy, such as their own independent thinking and decision-making. They should have their own clear understanding and planning about the status of the enterprise and strategic layout [28]. The autonomy also includes the international entrepreneur's sense of being able to control his own work independently, such as determining the working methods, working procedures, working hours and places, and how much effort to pay.

Relationship ability with society and government. International entrepreneurs should keep good relations with society and government to help enterprises access to valuable resources or reduce channel costs for the development of enterprises through their extensive relative network. Under the background of internationalization, enterprise management is the process of identifying, utilizing and developing opportunities under the condition of lacking resources [29]. One of the important tasks that international entrepreneurs must accomplish is to pave the way for internationalization of enterprises through contacts, and to shape the core advantages of enterprises.

Learning ability. American management scientist Drucker believes that entrepreneurs should not emphasize the professional depth, but should focus on general education and training. Bill Gates likes to conclude and imagine the future which is easy to make mistakes, but there is a very big advantage: correcting mistakes is faster than making mistakes. Entrepreneurship learning is a gradual process. In the face of challenges and opportunities in business development, entrepreneurial quality improves through a series of learning programs to be completed [30]. International business requires international entrepreneurs to continue to adapt to the new environment. The learning plan refers to the efforts made to obtain some knowledge and skills to solve new problems in business. It does not need to be developed in advance, and it is unconsciously to learn in the context of the environment. The learning process is to eliminate the gap between the current cognitive state and the expected state. Only through continuous learning, international entrepreneurs can continue to improve their own quality and ability.

Ability to overcome crisis and risks. In general, business risk will gradually increase with the degree of internationalization. If an operator sees only these potential risks, it is likely to give up making an international decision. True international entrepreneurs are not only aware of the risks while facing the risks, but are more concerned about the opportunities they bring [31]. Opportunities are contingent, but also objectivity. They are valuable resource and more perishable so that they cannot be stored. And if you give up once, perhaps your competitors will get. An excellent international entrepreneur makes a decision on the basis of rational analysis of potential risks. International entrepreneurs actively compete and dare to take the risk of the spirit so that they must seize the opportunities of international market, and even the expansion of international diversification.

Spirit of adventure. As a strategy to enter a new market, the international 
operations need to break the practice of domestic business and international business needs to bear greater risk. International entrepreneurs must have a bold and direct style, and must have the spirit of adventure and bold attempt. The premise of judging is that objective factors are as detailed and correct as possible, and their subjective factors should be as objective as possible, neutral and impartial. Under the condition of the separation of modern enterprises, managers of such entrepreneurs, although there is no collateral material capital or monetary capital to directly bear the operational risks, but in the perfect manager of the market, due to business failure will lead to damage to the reputation of entrepreneurs, the value of entrepreneurial human capital is greatly reduced, which constitutes the entrepreneurial human capital operating risk. At the same time, under the condition of perfect capital market, it is easy for international entrepreneurs to spirit their capital out to avoid the risk in the case of the risk of business operation. The human capital of the entrepreneur has the special nature and the huge exit cost, so the real risk is their human capital.

Managerial ability of international enterprises. Marshall pointed out that the best combination of factors of production cannot be automatically generated, and entrepreneurs must organize the production factors such as land, labor and capital. Only through the organization, capital and labor can be effectively used. In order to improve the efficiency of the cooperation of the owners of the resources, the international entrepreneurs should through the authorization and division of labor to arrange staff in proper position based the requirements of work and the characteristics of personnel [32]. Because of the need for organizational integration in the context of internationalization, international entrepreneurs need to get rid of the rigid traditional organizational model based on the entrepreneur's adaptation to the new environment and the elements of international business objectives. Nowadays, international enterprises are in a more and more competitive environment. In this state, international entrepreneurs are often required to have good management ability, so that enterprises can form a perfect system of plan, organization, supervision and control to have a healthy development.

Cognitive ability of international market. The ability of international entrepreneurs to recognize the international market can ensure that international business and international market change in a unified pace, and through strategic action to accurately locate in response to ongoing changes, including the international market events, trends, opportunities and challenges. In the process of international development of enterprises, enterprises scan the environment through the keen insight of the international entrepreneurs. International entrepreneurs are constantly able to discover business opportunities and the resources needed for business development and to discover, identify and capture opportunities for internationalization, which relies on their ability to correctly identify the situations of technological innovation, the international market development trends, strategic model selection and the development of competitors.

Innovation. Innovation refers to the ability to create new theories, new things 
and new things with certain social values. It is the core of the international entrepreneurs' ability and the ability to find new problems, put forward new ideas and solve new contradictions. Highly uncertainties and rapid changes are the hallmarks of each international business, so an innovative international entrepreneur should have the qualities of independent thinking, quick learning, rich imagination, keen observation and proactive problem solving.

Advance cognition and action. Advanced cognition and action refer that the international entrepreneurs not only value the market opportunity to predict, and take action in advance to deal with, and even take the initiative to shape the external environment through the first advantage and to enhance their own core competitiveness [33]. In the pursuit of overseas market opportunities, an excellent international entrepreneur is often daring to innovate and try. When in the introduction of some key business areas such as new products and services, operational processes and management methods, they try to be the leader of the market other than a follower.

Knowledge of international business. As an excellent international entrepreneur, he or she should have an open vision, solid international business theory and the foundation of international business law with the basic knowledge of statistics, accounting, economic law, marketing, finance and international trade. Rich international business knowledge and practical experience can help international entrepreneurs manager specialized collaboration and mass production well in a number of countries, regions and subsidiaries to deal with the affairs of law and finance around the world.

\subsection{Axial Coding}

Axial coding refers to the process of linking the various categories derived from open coding by using the model of causal condition, phenomenon, context, mediation condition, action or interaction strategy, and result. The model is an important analytical tool for grounded theory to link the categories and further explore the meaning of the categories. Using the context in which an event (the main category) is generated, the context in which the event depends (that is, the specific dimensions of the category) and the strategies and the results of the action taken by the actor in the event, to accurately grasp the event (the main category). Therefore, conditions, contexts, strategies and results are also categories, but are related to a main category and used to help understand the main category, so it is called sub-category. By means of axial coding, we can receive three main categories from seventeen sub-categories in Table 2.

\subsection{Selective Coding}

Selective coding refers to the selection of the core category, to systematically link to other categories and verify the relationship between them, and to accomplish the process of conceptualization which has not yet developed completely. Therefore, we can obtain the relationship among categories to build a competency model of international entrepreneurs from selective coding in Figure 1. The 
Table 2. Main categories from axial coding.

\begin{tabular}{cc}
\hline Sub-categories & Main Categories \\
Managerial professional knowledge & Knowledge \\
Language proficiency & \\
Knowledge of international business & \\
Managerial ability of international enterprises & \\
Cognitive ability of international market & Ability \\
Ability of international trade & \\
Ability to adapt to the dynamic environment & \\
Ability to integrate domestic and foreign resources & \\
Ability to overcome crisis and risks & \\
Relationship ability with society and government & \\
Learning ability & \\
Autonomy & \\
Innovation & \\
Change & \\
Advance cognition and action & \\
Competition enthusiasm & \\
Spirit of adventure & \\
\hline
\end{tabular}

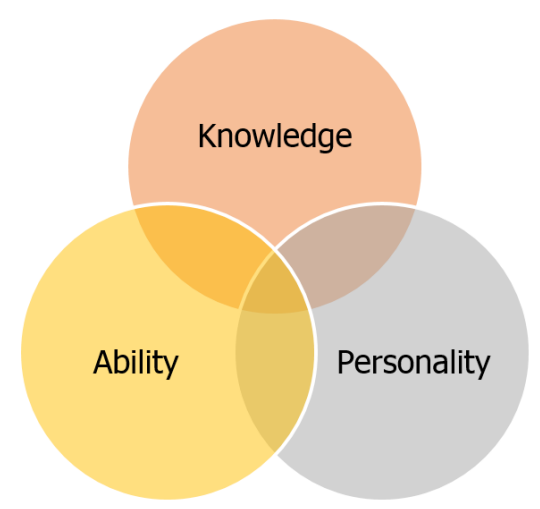

Figure 1. The relationship among categories from selective coding.

three main categories are closely related to each other.

\subsection{The Construction of the Competency Model}

The more complex international market international entrepreneurs are faced with, the more basic abilities and extensibility they must have, in order to ensure that their own abilities and qualities adapt to the steady and healthy development of leading enterprises [34]. The following table shows categories of modern international entrepreneurs in terms of abilities and qualities. They are divided into three main categories, Knowledge, Ability and Personality and subdivided into three, eight and six specific sub-categories, a total of seventeen sub-categories. These abilities and qualities are exactly must-haves of international entre- 
preneurs in leading enterprises in the modern sense.

Needless to say, by building such a model, especially interpreting related indicators systematically, it is not hard to see that in the training and promotion of qualities, and international entrepreneurs must make multiple efforts and have multiple qualities in the new era. Table 3 subdivides seventeen abilities and qualities that international entrepreneurs should possess and puts forward three kinds of targeted evaluation systems, which can be simply understood as "good, medium and poor". The criteria of these three systems are unified, from which we can see what kind of abilities and qualities an excellent international entrepreneur should possess. For example, "the ability to integrate domestic and foreign resources" under Ability is a very vital ability for modern entrepreneurs and determines whether entrepreneurs can obtained required resources for corporate development in extremely complex international market competition. The evaluated content of three evaluation systems are "strong ability to search, integrate and allocate domestic and foreign resources and maximize the use of resources", "basic ability to allocate domestic and foreign resources, but short of flexibility and creativity", "inadequate awareness and insight to integrate domestic and foreign resources, seriously inadequate practical ability". From the evaluation of such criteria, it can be seen that really good international entrepreneurs must be equipped with advanced thinking and awareness, while possessing good ability to execute. Only when all resources and information are mobilized can entrepreneurs play a role of leaders and make contributions to the sustainable development of enterprises.

Again, whether international entrepreneurs have strong learning abilities actually determines whether they keep up with the fast knowledge update and constantly acquire new knowledge and information, to be used in the work of leading enterprises. So the criteria for three main categories are "strong thirst for knowledge, good learning habits and thinking habits, enthusiastic about learning; thirst for knowledge and learning, but short of a strong sense of mission in learning, insufficient time; complacent, self-righteous, incorrect cognition of learning". It can be seen that the evaluations of three main categories correspond to three kinds of entrepreneurs, who are entirely different. Their attitudes towards learning, readers and progress are also diametrically different. Excellent entrepreneurs always seize time to read, learn and grasp a wealth of knowledge. While complacent and self-righteous entrepreneurs basically lose the interest and ability to learn. Their thoughts are nearly stereotyped. So excellent qualities and abilities of international entrepreneurs are essentially identical, that is, to respect the development of times and progress of society, have a strong desire for knowledge and advance and take a variety of measures to improve themselves.

Moreover, it is well-known that innovation awareness and innovation ability are of vital importance for international entrepreneurs and even, to a certain extent, determine whether they can better adapt to changing demands of innovative society and international market. In the competency model of international 
Table 3. A competency model of international entrepreneurs.

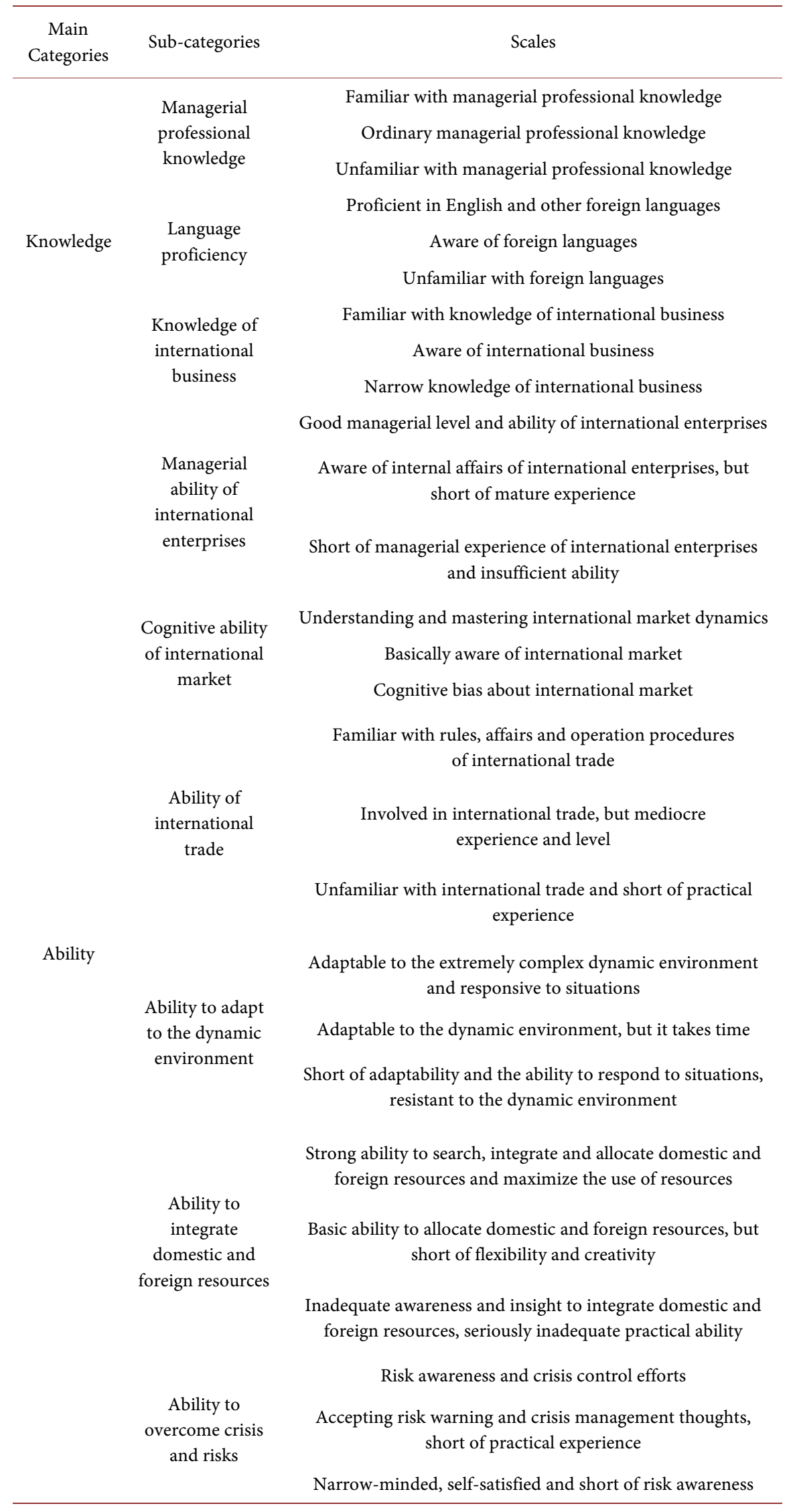




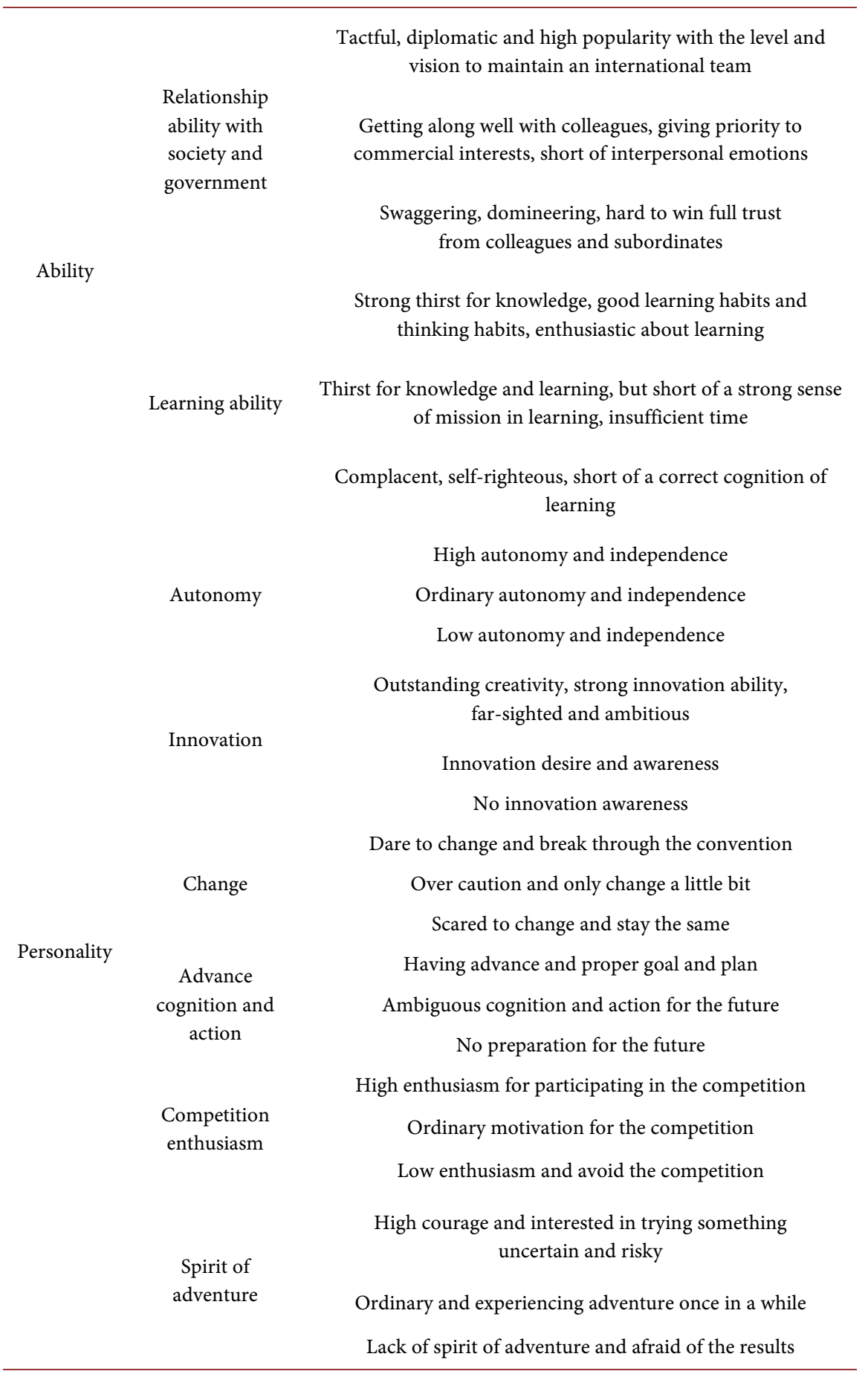

entrepreneurs shown in Table 3, the sub-category of "innovation" can be subdivided into three scales, i.e., "outstanding creativity, strong innovation ability, far-sighted and ambitious; innovation desire and awareness; no innovation awareness". It can be seen that excellent international entrepreneurs must possess advanced innovation awareness and innovation ability. Mediocre and even unqualified international entrepreneurs lack innovative thinking and abilities. This is an issue that should arouse our attention. 


\section{Conclusions}

By means of depth interviews and grounded theory, this study builds a competency model of international entrepreneurs, including three main categories and seventeen sub-categories. The first main category is Knowledge, including three sub-categories, such as managerial professional knowledge, language proficiency and the knowledge of international business. The second main category is Ability, including eight sub-categories, such as the managerial competencies of international enterprises, cognitive ability of international market, the ability of international trade, the ability to adapt to the dynamic environment, the ability to integrate domestic and foreign resources, the ability to overcome crisis and risks, relationship ability with society and government and learning ability. The third main category is Personality, including six sub-categories, such as autonomy, innovation, change, advance cognition and action, competition enthusiasm and the spirit of adventure. The grounded theory used in the article is a qualitative method. Although there have been standardized procedures, reliability and validity are still widely questioned in comparison with quantitative methods. In the future, scholars can combine questionnaires, second-hand data or other methods to analyze the different categories of the competency model about international entrepreneurs more deeply.

It is not hard to see that international entrepreneurs in the new era must be far-sighted and ambitious, possess innovative thinking and abilities, build up an international view and abilities realistically and make progress through constant improvement and thirst for knowledge. Meanwhile, they should strengthen personal and cognitive qualities. Only when multiple qualities of international entrepreneurs are enhanced and core competitiveness of international enterprises is formed, can it contribute to healthy, stable and sustainable development.

\section{References}

[1] Light, I., Rezaei, S. and Dana, L. (2013) Ethnic Minority Entrepreneurs in the International Carpet Trade: An Empirical Study. International Journal of Entrepreneurship and Small Business, 18, 125-153. https://doi.org/10.1504/IJESB.2013.052055

[2] Gray, L. (1999) New Zealand HRD Practitioner Competencies: Application of the ASTD Competency Model. International Journal of Human Resource Management, 10, 1046-1059. https://doi.org/10.1080/095851999340116

[3] Sieger, P., Gruber, M., Fauchart, E. and Zellweger, T. (2016) Measuring the Social Identity of Entrepreneurs: Scale Development and International Validation. Journal of Business Venturing, 31, 542-572. https://doi.org/10.1016/j.jbusvent.2016.07.001

[4] Glavas, C., Pike, S. and Mathews, S. (2014) Internet-Enabled Tourism Entrepreneurs. International Entrepreneurial Values Elicited Through Repertory Test and Laddering Analysis. International Journal of Tourism Research, 16, 44-55. https://doi.org/10.1002/jtr.1896

[5] Ellis, P.D. (2011) Social Ties and International Entrepreneurship: Opportunities and Constraints Affecting Firm Internationalization. Journal of International Business Studies, 42, 99-127. https://doi.org/10.1057/jibs.2010.20

[6] Sigfusson, T. and Harris, S. (2013) Domestic Market Context and International En- 
trepreneurs' Relationship Portfolios. International Business Review, 22, 243-258. https://doi.org/10.1016/j.ibusrev.2012.04.008

[7] Chang, F.Y.M., Jack, R. and Webster, C.M. (2017) Pre and Post-Entry Resource Needs for International Entrepreneurs: The Role of Government and Industry Networks. Journal of Management \& Organization, 23, 186-205. https://doi.org/10.1017/jmo.2016.52

[8] Pérez-López, M.C., González-López, M.J. and Rodríguez-Ariza, L. (2016) Competencies for Entrepreneurship as a Career Option in a Challenging Employment Environment. Career Development International, 21, 214-229. https://doi.org/10.1108/CDI-07-2015-0102

[9] Zahra, S.A. and George, G. (2002) International Entrepreneurship: The Current Status of the Field and Future Research Agenda. In: Strategic Entrepreneurship: Creating a New Mindset, Blackwell Publishers, Oxford, 255-288.

http://ink.library.smu.edu.sg/lkcsb_research/4716

[10] Morrow J.F. (1988) International Entrepreneurship: A New Growth Opportunity. New Management, 3, 59-61.

[11] Oviatt, B.M. and McDougall, P.P. (1994) Toward a Theory of International New Ventures. Journal of International Business Studies, 25, 45-64. https://doi.org/10.1057/palgrave.jibs.8490193

[12] Wright, R.W. and Ricks, D.A. (1994) Trends in International Business Research: Twenty-Five Years Later. Journal of International Business Studies, 25, 687-701. https://doi.org/10.1057/palgrave.jibs.8490219

[13] McDougall, P.P. and Oviatt, B.M. (1997) International Entrepreneurship Literature in the 1990s and Directions for Future Research. Upstart Publishing, Chicago.

[14] Shane, S. and Venkataraman, S. (2000) The Promise of Entrepreneurship as a Field of Research. Academy of Management Review, 25, 217-226. https://doi.org/10.5465/AMR.2000.2791611

[15] Oviatt, B.M. and McDougall, P.P. (2005) Defining International Entrepreneurship and Modeling the Speed of Internationalization. Entrepreneurship: Theory \& Practice, 9, 537-553. https://doi.org/10.1111/j.1540-6520.2005.00097.x

[16] Christopher, C.A. (2011) Religion in Entrepreneurship: How International and Indigenous Indian Entrepreneurs Differ. International Journal of Entrepreneurship and Small Business, 13, 411-428. https://doi.org/10.1504/IJESB.2011.041836

[17] Hu, M.M. (2010) Developing a Core Competency Model of Innovative Culinary Development. International Journal of Hospitality Management, 29, 582-590. https://doi.org/10.1016/j.ijhm.2009.10.024

[18] Zhou, L. (2007) The Effects of Entrepreneurial Proclivity and Foreign Market Knowledge on Early Internationalization. Journal of World Business, 42, 281-293. https://doi.org/10.1016/j.jwb.2007.04.009

[19] Maral, M.T. (2009) Why a Multinational Company Introduces a Competency-Based Leadership Model: A Two-Theory Approach. International Journal of Human Resource Management, 20, 606-632. https://doi.org/10.1080/09585190802707383

[20] Coviello, N.E. and Jones, M.V. (2004) Methodological Issues in International Entrepreneurship Research. Journal of Business Venturing, 19, 485-508. https://doi.org/10.1016/j.jbusvent.2003.06.001

[21] Bloodgood, J.M., Hornsby, J.S., Burkemper, A.C. and Sarooghi, H. (2015) A System Dynamics Perspective of Corporate Entrepreneurship. Small Business Economics, 45, 1-20. https://doi.org/10.1007/s11187-015-9634-4

[22] Keupp, M.M. and Gassmann, O. (2009) The Past and the Future of International 
Entrepreneurship: A Review and Suggestions for Developing the Field. Journal of Management, 35, 600-633. https://doi.org/10.1177/0149206308330558

[23] Coviello, N.E., Mcdougall, P.P. and Oviatt, B.M. (2011) The Emergence, Advance and Future of International Entrepreneurship Research-An Introduction to the Special Forum. Journal of Business Venturing, 26, 625-631. https://doi.org/10.1016/j.jbusvent.2011.07.002

[24] Glaser, B.G. and Strauss, A.L. (1967) The Discovery of Grounded Theory: Strategies for Qualitative Research. Aldine Publishing Company, Chicago.

[25] Charoensukmongkol, P. (2015) Cultural Intelligence of Entrepreneurs and International Network Ties. Management Research Review, 38, 421-436. https://doi.org/10.1108/MRR-09-2013-0214

[26] Shirokova, G., Tsukanova, T. and Bogatyreva, K. (2015) University Environment and Student Entrepreneurship: The Role of Business Experience and Entrepreneurial Self-Efficacy. Educational Studies, 3, 171-207. https://doi.org/10.17323/1814-9545-2015-3-171-207

[27] Rahman, S.A., Amran, A., Ahmad, N.H. and Taghizadeh, S.K. (2016) Enhancing the Wellbeing of Base of the Pyramid Entrepreneurs through Business Success: The Role of Private Organizations. Social Indicators Research, 127, 195-216. https://doi.org/10.1007/s11205-015-0951-4

[28] Munoz-Bullon, F., Sanchez-Bueno, M.J. and Vos-Saz, A. (2015) Nascent Entrepreneurs' Personality Attributes and the International Dimension of New Ventures. International Entrepreneurship and Management Journal, 11, 473-492. https://doi.org/10.1007/s11365-013-0284-1

[29] Sigfusson, T. and Harris, S. (2012) The Relationship Formation Paths of International Entrepreneurs. Journal of International Entrepreneurship, 10, 325-349. https://doi.org/10.1007/s10843-012-0095-4

[30] Koenigsfeld, J.P., Kim, S.H., Cha, J.M., Perdue, J. and Cichy, R.F. (2012). Developing a Competency Model for Private Club Managers. International Journal of Hospitality Management, 31, 633-641. https://doi.org/10.1016/j.ijhm.2011.08.007

[31] Kehoe, T.J., Pujolas, P.S. and Ruhl, K.J. (2016) The Opportunity Costs of Entrepreneurs in International Trade. Economics Letters, 146, 1-3. https://doi.org/10.1016/j.econlet.2016.07.012

[32] Morris, M.H., Webb, J.W., Fu, J. and Singhal, S. (2013) A Competency-Based Perspective on Entrepreneurship Education: Conceptual and Empirical Insights. Journal of Small Business Management, 51, 352-369. https://doi.org/10.1111/jsbm.12023

[33] Dimitratos, P. and Jones, M.V. (2005) Future Directions for International Entrepreneurship Research. International Business Review, 14, 119-128. https://doi.org/10.1016/j.ibusrev.2004.06.003

[34] Wilkinson, D. (2004) The CICA's IT Competency Model. International Journal of Accounting Information Systems, 5, 245-250.

https://doi.org/10.1016/j.accinf.2004.04.003 
Submit or recommend next manuscript to SCIRP and we will provide best service for you:

Accepting pre-submission inquiries through Email, Facebook, LinkedIn, Twitter, etc. A wide selection of journals (inclusive of 9 subjects, more than 200 journals)

Providing 24-hour high-quality service

User-friendly online submission system

Fair and swift peer-review system

Efficient typesetting and proofreading procedure

Display of the result of downloads and visits, as well as the number of cited articles Maximum dissemination of your research work

Submit your manuscript at: http://papersubmission.scirp.org/

Or contact jssm@scirp.org 